\title{
Redefining massive transfusion
}

\author{
Thomas C König*, Timothy Morris, Christine Gaarder, Marc Maegele, \\ Carel Goslings, Shuba Allard, Mitchell Cohen, Jean Francois Pittet, \\ Pär Johansson, Simon Stanworth and Karim Brohi
}

Address: Royal London Hospital Trauma Clinical Academic Unit, Royal London Hospital, Whitechapel, London E1 1BB, UK

Email: Thomas C König* - tom.konig@bartsandthelondon.nhs.uk

* Corresponding author

from The Third Annual London Trauma Conference

London, UK. 12-14 November 2008

Published: 24 February 2009

Scandinavian Journal of Trauma, Resuscitation and Emergency Medicine 2009, 17(SuppI I):OI doi:I0.I I86/I757-724I-I7-SI-OI

This abstract is available from: http://www.sjtrem.com/content/I7/SI/OI

(C) 2009 König et al; licensee BioMed Central Ltd.

\section{Background}

The concept of massive transfusion was developed to trigger clotting factor therapy for the treatment of coagulopathy due to dilution, after a certain number of units of packed red blood cells. It has been defined as the replacement of circulating volume or the transfusion of more than 6 or 10 units of packed red blood cells (PRBC) in the 24 hours after injury. Until recently there has been little consideration of the transfusion of clotting products. Given the recent identification of the early coagulopathy of trauma and the new therapeutic regimens for massive transfusion, there is therefore a need to re-examine the concept of massive transfusion.

\section{Aims}

To determine if there is a clinically relevant definition of massive transfusion based on outcome.

\section{Methods}

A retrospective multi centre registry analysis of the transfusion practices of five centres in Europe and North America was carried out. 5150 patients were studied. Data was collected on demographics, mechanism of injury, 24 hour PRBC requirement and mortality.

\section{Results}

There was a linear increase in the number of PRBC transfused and mortality (Figure 1). No clear threshold above which mortality increased was found. Each additional unit of blood transfused added cumulatively less to the mortality risk (Figure 2).

\section{Conclusion}

The current definitions of massive transfusion are arbitrary and do not select patients on the basis of outcome. The differences in transfusion practices amongst centres

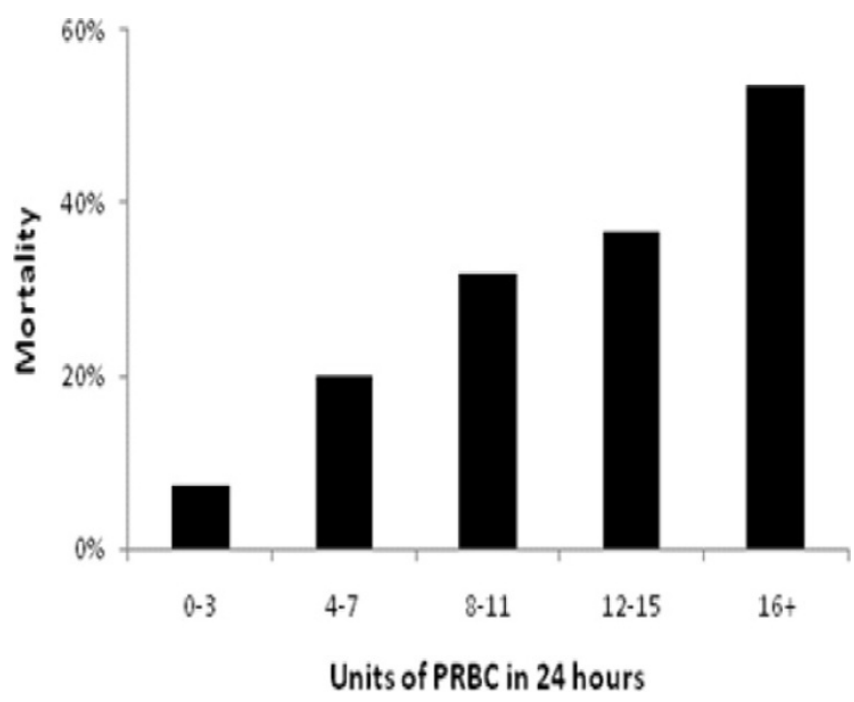

Figure I 


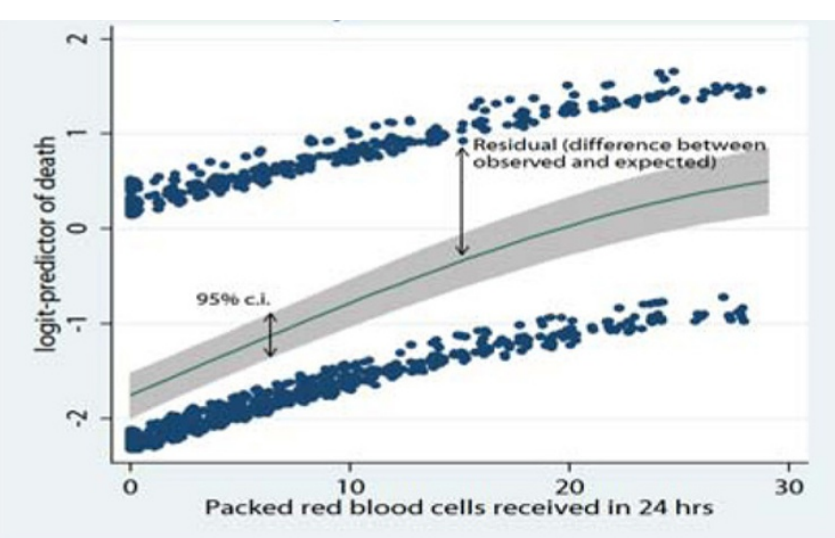

Figure 2

around the world and the change in the treatment of the coagulopathy of trauma with PRBC and use of blood products in higher ratios may mean that massive transfusion has become an outdated concept.
Publish with Bio Med Central and every scientist can read your work free of charge

"BioMed Central will be the most significant development for disseminating the results of biomedical research in our lifetime. "

Sir Paul Nurse, Cancer Research UK

Your research papers will be:

- available free of charge to the entire biomedical community

- peer reviewed and published immediately upon acceptance

- cited in PubMed and archived on PubMed Central

- yours - you keep the copyright

Submit your manuscript here:

http://www.biomedcentral.com/info/publishing_adv.asp 